\title{
PIGMENTARY UVEITIS ASSOCIATED WITH IRIDOCILIARY CYSTS IN AMERICAN BULLDOGS
}

\author{
Jorge da Silva Pereira ${ }^{1}$, Eva Martínez Rincón ${ }^{1}$, Manuel Villagrasa-Hijar¹, Amália \\ Turner Giannico', Fabiano Montiani-Ferreira ${ }^{1}$ \\ 1 UFPR \\ Correspondência: Fabiano Montiani-Ferreira: montiani@ufpr.br
}

\begin{abstract}
Presence of iridociliary cysts may cause a specific form of uveitis not associated with any known systemic disease or underlying cause. The condition was previously characterized in Golden Retrievers. However, Labrador Retrievers, Great Danes and Boston Terriers are reported to develop a similar disease condition. The following report documents seven cases of iridociliary cysts, with or without associated pigmentary uveitis, in American Bulldogs from Brazil and Spain. Although not an uncommon disease, this syndrome has been relatively infrequently documented in the literature, with only one study in the American Bulldog. This article describes clinical findings as well as medical and surgical management of each case. Because some of the patients were closely related in this series, a possible hereditary basis is considered for pigmentary uveitis associated with iridociliary cysts in American Bulldogs.
\end{abstract}

Key Words: cysts; dog; pigmentary uveitis

\section{UVEÍTE PIGMENTAR ASSOCIADA A CISTOS IRIDOCILIARES EM BULDOGUES AMERICANOS}

RESUMO: A presença de cistos no corpo ciliar pode causar uma forma específica de uveíte não associada a qualquer doença sistêmica conhecida ou a causas subjacentes. A condição já foi caracterizada anteriormente em cães da raça Golden Retriever. No entanto, há relatos do desenvolvimento de uma condição similar nas raças Labrador Retriever, Great Dane e Boston Terrier. Neste trabalho, sete casos de cistos de corpo ciliar são relatados em cães da raça Buldogue Americano, sendo que estes apresentaram ou não uveíte pigmentar associada. Apesar de não ser rara, a síndrome tem sido relativamente pouco documentada na literatura, com apenas um trabalho no Buldogue Americano. Descrevem-se aqui os achados clínicos, bem como condutas clínica e cirúrgica em cada caso. Como alguns dos pacientes tinham consanguinidade, considera-se como possível a base hereditária para as uveítes pigmentares associadas com cistos no Buldogue Americano.

Palavras-chave: cistos; cão; uveíte pigmentar 


\section{INTRODUCTION}

Iris and ciliary body cysts are a frequent incidental finding in dogs and may be either congenital or acquired (Jensen, 1971; Gelatt et al., 1979; Pumphrey et al., 2013). Due to the fact that most uveal cysts occur in middleaged and older dogs, has been suggested that the majority of cysts are acquired, with trauma or inflammation proposed as probable causes. Conversely, cysts could be the progression of congenital lesions, remaining undetectable until several years of age (Duke-Elder, 1963; Corcoran; Koch, 1993). Golden Retrievers, Labrador Retrievers, and Boston Terriers are reported to be more predisposed to develop uveal cysts (Corcoran; Koch, 1993).

Transillumination techniques help recognize iris cysts, which arise from the posterior iris epithelium and are, therefore, strongly pigmented but hollow (Carter; Mausolf, 1970). Ciliary body cysts, on the other hand, are poorly pigmented. Free cysts are often observed as floating structures in the anterior chamber. However, they may rupture or even collapse against iridal or corneal surfaces (Duke-Elder, 1963; Bedford, 1980; Bowman et al., 1988). Ultrasonic biomicroscopy (UBM) can provide additional diagnostic information. A detailed ultrasound can accurately localize and precisely measure the lesion, providing an indispensable method for monitoring change or growth (Pavlin et al., 1992). In instances where an area of elevated iris is seen and using traditional techniques the lesion is not visualised, UBM can eliminate any uncertainties. Ultrasonic biomicroscopy of a pigment epithelial cyst typically shows a highly reflective, smooth cyst wall with no internal reflectivity or solid component (Pavlin et al., 1992).
Some confusion surrounds the terminology used to describe the presence of iridociliary cysts causing a specific form of uveitis, that is not associated with any known systemic disease or underlying cause. The degree of uveitis described in the literature in these cases varies. Histological features of the disease described in Golden Retrievers indicate the term 'uveitis' may not be entirely appropriate due to the inconsistency of inflammation observed in the cystic disease (Esson et al., 2009). Protein and cellular material in the aqueous may be due to the escape of protein-rich cyst contents and cellular debris due to contact between cysts and the lens or cornea. This causes pigment deposits in different intraocular tissues and might cause the clinician to overestimate the degree of uveal inflammation (Deehr; Dubielzig, 1998).

Iridociliary cysts syndrome resulting in glaucoma have been described in Great Danes and Golden Retrievers (Peiffer; Gelatt, 1976; Spiess et al.,1998; Sapienza et al., 2000). Minimal uveitis was clinically observed in these Great Danes. However, histologically in each case there was some degree of fibrovascular tissue proliferation in the anterior segment covering the drainage angle and the anterior surface of the iris (Spiess et al.,1998). In American Bulldogs three cases of glaucoma associated with uveal cysts and goniodysgenesis were observed in histopathological examination showed significant preiridal fibrovascular membrane formation and mononuclear inflammatory infiltrates in the anterior uvea (Pumphrey et al., 2013).

The purpose of the autors is to report the clinical features of uveal cysts in seven American Bulldogs. 


\section{CASE PRESENTATION}

Patients were presented with the complain of chronic bilateral or unilateral eye reddish, blepharospasm, excessive tearing sometimes staining the medial canthus. They all had previously received treatment for conjunctivitis, through the use of broad spectrum antibiotics and antinflamatory eyedrops, with no noticed improvement. A quick primary observation allowed us to confirm the condition of red eye, episcleral injection at different levels in different patients. Some eyes had miosis and cysts could be observed in the anterior chamber, which are of different sizes. Blood tests previously taken by clinicians who referred patients, allowed discard any systemic condition commonly associated with the clinical presentation.

\section{Diagnosis}

The diagnosis of the condition was based upon finding multiple pigmented cysts using slit lamp biomicroscopy (SL15 Kowa®, Japan), indirect ophthalmoscopy (Welch Allyn®, USA), tonometry (Tonopen Avia, Reichert $\AA$, USA), and gonioscopy (Magonio, Volk Optical ${ }^{\circledR}$, USA), were also performed. Hematological, biochemical and serologic testing were performed to exclude infectious agents.

In three cases (Cases 4, 5 and 6 - Table 1) UBM was performed (Linear $50 \mathrm{MHz}$ UBM Probe, Quantal Medical®, France). During UBM examination, presence and location of the cysts could be confirmed (Figure 1). In all cases, UBM was also useful to evaluate the cysts.
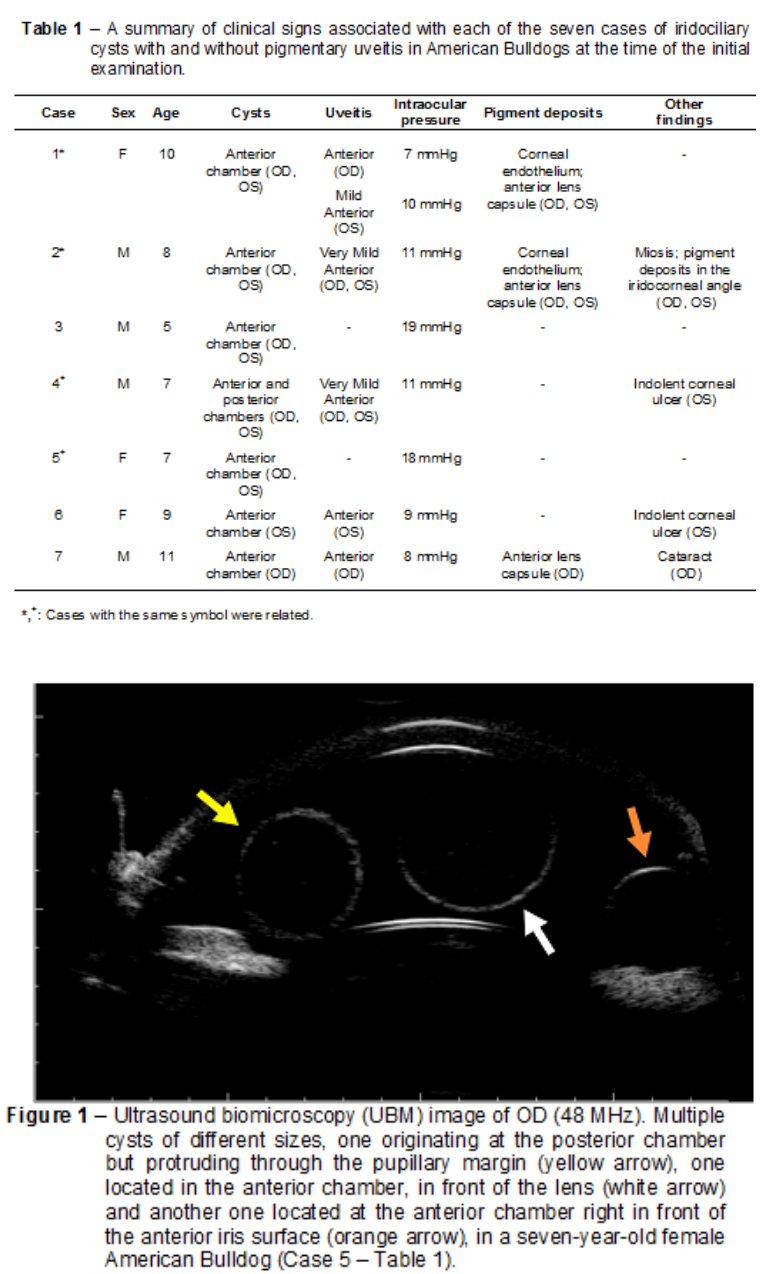

\section{Clinical findings}

Seven American Bulldogs were identified and diagnosed with iridociliary cysts with or without associated pigmentary uveitis. Four dogs were diagnosed with the condition in Spain and three dogs in Brazil. Two dogs were affected in only one eye at the initial examination (1-OS; 1-OD) (Cases 6 and 7 - Table 1). Three female and four males were examined with the ages ranging from 5 to 11 years (mean $8.14 \pm$ 2.04).

Pigment deposits were observed in $3 / 7$ animals on different ocular tissues. In two cases (Cases 1 and 2 Table 1) collapsed cysts and pigment deposits were observed in the corneal endothelium and in the anterior lens capsule (Figure 2). Uveal cysts were observed with and without an associated anterior lens capsular and endothelial pigmentation. In all animals multiple cysts were observed in the anterior 
chamber (Figure 3a) and in one animal (Case 4 - Table 1), cysts were also totally or partially found in the posterior chamber (Figure 3b). These cysts varied in size and amount of pigmentation, ranging from transparent, lightly pigmented (Figure 3c) or even strongly pigmented (Figure 3d).
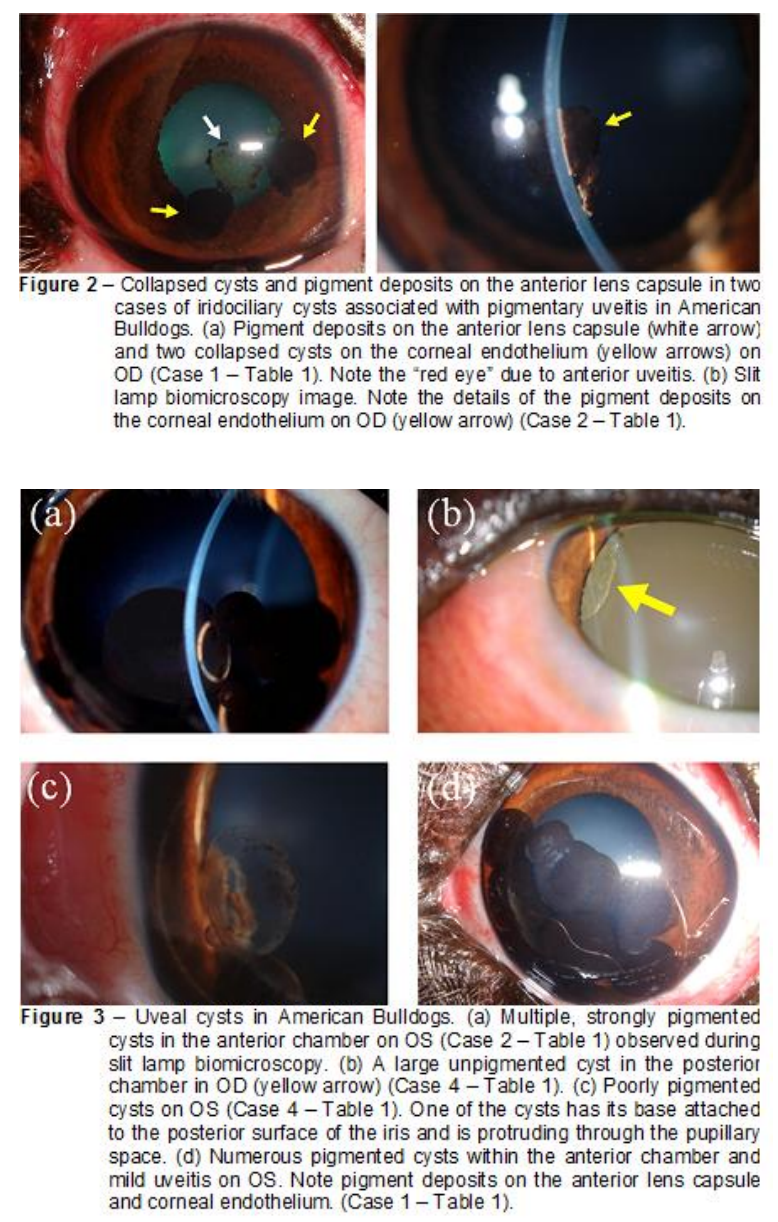

Uveitis, when present varied in intensity and was diagnosed in all cases via observing classical clinical signs, a combination of blepharospasm, flare and episcleral congestion ("red eye"), and, sometimes lowering of intraocular pressure (IOP). Uveitis was clincially diagnosed in five of the seven patients examined, in wich red eyes were presented and cysts observed. Also flare could be noticed in the anterior chamber and the IOP ranged from $7 \mathrm{mmHg}$ to 11 $\mathrm{mmHg}$. Uveitis was more severe in eyes that had numerous pigmented iris cysts. In these cases tearing and painful eyes, corneal edema, iris redness and flare in the anterior chamber, third eyelid protrusion and the pupil tended to be small, reacting slightly to light.

Other clinical observations included: severe miosis in one animal, pigment deposits present at the iridocorneal angle, observed through gonioscopy. Cataract in one animal, indolent corneal ulcers in two animals (Table 1). No other systemic causes could be identified in any animal that could explain the clinical diagnostic of the uveitis.

\section{Treatment}

Two animals were treated with surgical extraction of the cysts using the aspiration technique (Cases 1 and 2 Table 1). Laser neodymium-doped yttrium aluminium garnet (Nd-YAG laser) surgery was performed in two other cases (Cases 4 and 5 - Table 1). Recurrence of the cysts in the anterior chamber occurred in both eyes in case 4 and in left eye in case 5 one year after the Nd-YAG laser procedure was performed. Treatments for pigmentary uveitis included topical corticosteroid (fluorometholone acetate $0.1 \%$, one drop TID), unless corneal ulcers were detected. When corneal ulcers were detected, a non steroidal antiinflammatory topical drug (nepafenac $0.1 \%$, one drop $\mathrm{TID}$ ). Indolent ulcers, when present were treated with debridement and bandage lenses. Pulse therapy with systemic corticosteroid (prednisolone, $1 \mathrm{mg} / \mathrm{kg}$ every other day) and anti glaucomatous preventive eye drop (timolol maleate $0.5 \%$, one drop BID), were prescribed. Enucleation was not necessary in any patient.

Other findings (Table 1) were treated appropriately using medical and/or surgical techniques. Indolent corneal ulcers were treated with bandage lenses after epithelium debridement in two dogs. Phacoemulsification surgery was 
performed and an intraocular lens was implanted in the dog with cataracts.

\section{Pedigree information}

A possible genetic factor might be involved in these cases of iridociliary cysts observed in the American Bulldogs described here. Although we have reported few cases in this breed was noted that they have a parental relations. A total of four cases were observed in Spain, two of which were siblings from the same litter (Cases 4 and 5 - Table 1). Three cases were diagnosed in Brazil, two of which were also siblings, though they were from different litters (Cases 1 and 2 - Table 1).

\section{DISCUSSION}

Presence of pigmentary uveitis associated with iridociliary cysts in American Bulldogs is characterized by the presence of iridociliary cysts, pigment dispersion into lenticular, iridal, and corneal endothelial surfaces in addition to a variable degree of uveitis. A similar condition has been described in Golden Retriever dogs (Sapienza et al., 2000; Corcoran; Koch, 1993; Esson et al., 2009).

To our knowledge, pigmentary uveitis associated with iridociliary cysts as a disease entity was reported only once in the American Bulldog (Pumphrey et al., 2013). Golden Retrievers, Labrador Retrievers, Great Danes and Boston Terriers are most frequently reported to develop a similar disease condition (Esson et al., 2009). Angle closure glaucoma secondary to iris and ciliary body cysts has been previously described in human beings, and an autosomal dominant hereditary pattern was suggested (Vela et al., 1983).

Glaucoma is described as frequent complication of uveitis associated with iridociliary cysts in the
Great Dane and in the Golden Retriever (Spiess et al.,1998, Sapienza et al., 2000, Esson et al., 2009). The mechanism of glaucoma development secondary to iridociliary cysts is multifactorial and may include: mechanical angle closure by the cysts, 'plateau iris syndrome', which is a rare form of angle closure glaucoma, heavy deposition of pigment in the filtration angle, pupillary block, release of cystic contents and inflammatory cellular infiltration blocking the aqueous outflow (Deehr; Dubielzig, 1998, Spiess et al.,1998, Sapienza et al., 2000). We did not observe glaucoma in the cases reported but it may be noticed in future, as noticed elsewhere in these breed (Pumphrey et al., 2013), perhaps with the observation of more patients, with a longer term follow up. In other hands, those patients who presented normal IOP could be compensated with the effect of lowering IOP by the presence of uveitis. Thus, American Bulldogs with uveal cysts should be monitored carefully for signs of inflammation and increased intraocular pressure. Our treatment option was direct to surgically remove the cysts, controlling the uveitis, as well as preventing the secondary glaucoma installation. Once it was not needed to enucleate any eyes to date, we do not present microscopic findings.

Sapienza et al. (2000) documented the clinical course of a similar condition in 75 Golden Retrievers, demonstrating progressive anterior uveitis, often associated with the presence of cystic structures. In our study, the condition was diagnosed in a similar age range in which golden retrievers were diagnosed. Similarly, most of the American Bulldogs were bilaterally affected. Additionally, hematological, biochemical and serologic testing for infectious agents failed to demonstrate an underlying etiology in both our study and Sapienza et al. (2000). 
The fact that this disease condition was observed in dogs of the same breed, with four out of the seven cases having siblings with the same disease, to some extent suggest a hereditary basis. With such a small number of animals in this study it is impossible to determine heritability. Additionally, we were not able to discern whether the cysts were congenital or acquired.

Because most uveal cysts are benign and generally do not interfere with vision, cysts usually do not require treatment (Hendrix , 2008). However, attached or floating uveal cysts that occlude the pupil or multiple pigmented cysts that may lead to angle closure may be aspirated with a small gauge needle or deflated with a laser (Hendrix, 2008). In these cases presented by us, two animals were treated with surgical extraction of the cysts using the aspiration technique and in others two cases Nd-YAG laser surgery was performed. Curiously, recurrence of the cysts occurred in eyes receiving treatment with a more sophisticated and presumably more effective technique (Nd-YAG laser). Nevertheless, performing mechanical aspiration, this not occured. In these reports, some animals developed uveitis having the primary cause the presence of cysts. Therapy should be directed against clinical uveitis to minimize the occurence of glaucoma. Topical corticosteroids are commonly used for this, as performed by us (Sapienza et al., 2000). In the case of ulcer, topical nonsteroidal agents can be prescribed, but often resulted in an exacerbation of increased IOP (Millichamp et al., 1991; Sapienza et al., 2000). Even with standard uveitis therapy and treatment of secondary glaucoma, the prognosis for long-term vision is guarded with this disease (Millichamp et al., 1991).

\section{CONCLUSION}

Pigmentary uveitis associated with iridociliary cysts as a clinical entity is observed in American Bulldogs living in Spain and in Brazil and is described here for the second time. Further clinical investigations of additional cases with a more extensive pedigree analysis are necessary to determinate if an hereditary basis is present and also if the condition is the same already described in golden retrievers (Sapienza et al. 2000).

\section{ACKNOWLEDGEMENTS}

The authors thank Dr. Gillian Shaw, Johns Hopkins University, Baltimore, MD, USA, for her invaluable help in the preparation of this manuscript.

\section{REFERENCES}

BEDFORD, P.G.C. The anterior uveal cyst as an unusual cause of corneal pigmentation in the dog. Journal of Small Animal Practice v.21, n.2, p.97-101, 1980.

BOWMAN, Z.; PEIFFER, R.L.JR.; BOULDIN, T.W. Pathogenesis of ciliarybody cysts associated with multiple myeloma. Annals of Ophthalmology v.20, n.8, p 292-295, 1988.

CARTER, J.; MAUSOLF, F. Clinical and histologic features of pigmented ocular cysts. Journal of the American Animal Hospital Association v.6, p.194-200, 1970.

CORCORAN, K.A.; KOCH, S.A. Uveal cysts in dogs: 28 cases. Journal of the American Veterinary Medical Association v.203, n 4, p.545-546, 1993.

DEEHR, A.J.; DUBIELZIG, R.R. A histopathological study of iridociliary cysts and glaucoma in Golden Retrievers. Veterinary Ophthalmology v.1, n.1, p.153-158, 1998.

DUKE-ELDER, S. Congenital Deformities. In: System of ophthalmology. v.3,n. 2, p.565-622, 1963.

ESSON, D.; ARMOUR, M.; MUNDY, P. et al. The histopathological and immunohistochemical characteristics of pigmentary and cystic 
glaucoma in the Golden Retriever. Veterinary

Ophthalmology v.12, n.6, p.361-368, 2009.

GELATT, K.N.; JOHNSON, K.A.; PEIFFER, R.L. Primary iridal pigmented masses in three dogs. Journal of the American Animal Hospital Association v.15, n.3, p.339-344, 1979.

HENDRIX, D.V.H. Diseases and surgery of the canine anterior uvea. In: GELATT, K.N. Essentials of Veterinary Ophthalmology. 2nd ed. Ames, lowa, Blackwell Publishing, p. 189216, 2008.

JENSEN, H.E. Stereoscopic atlas of ophthalmology of domestic species. St Louis, CV, Mosby. p.120-139, 1971.

MILLICHAMP, N.J.; DZIEZYC, J.; OLSEN, J.W. Effect of flurbiprofen on facility of aqueous outflow in the eyes of dogs. American Journal of veterinary Research v.52, n.9, p.1448-1451, 1991.

PAVLIN, C.J.; MCWHAE, J.A.; MCGOWAN, H.D. et al. Ultrasound biomicroscopy of anterior segment tumors. Ophthalmology v.99, n.8, p.1220-1228, 1992.

PEIFFER, R.L.JR.; GELATT, K.N. Multiple iridal cysts and a cortical cataract in a dog. Journal of Veterinary Medicine, Small Animal Clinician v.71, n.4, p.445-446, 1976.

PUMPHREY, A.S.; PIZZIRANI, S.; PIRIE, C.G. et al. Glaucoma associated with uveal cysts and goniodysgenesis in American Bulldogs: a case series. Veterinary Ophthalmology v.16, n.5, p.377-385, 2013.

SAPIENZA, J.S.; DOMENECH, F.J.S.;

SAPIENZA, A.P. Golden Retriever uveitis: 75 cases (1994-1999). Veterinary Ophthalmology v.3, n.4., p.241-246, 2000.

SPIESS, B.M.; BOLLIGER, J.O.; GUSCETTI, F. et al. Multiple ciliary body cysts and secondary glaucoma in the Great Dane: a report of nine cases. Veterinary Ophthalmology v.1, n.1, p.41-45, 1998.

VELA, A., REISER, J.C.; CAMBELL, D.G. The heredity and treatment of angle closure glaucoma secondary to iris and ciliary body cysts. Ophthalmology v.91, n.4., p.332-337, 1983. 